\title{
1 Finding Treasures: Is the Community of Philosophical Inquiry 2 a Methodology?
}

\author{
3 Walter Omar Kohan ${ }^{1}$ (D) . Magda Costa Carvalho ${ }^{2,3}$ (D) \\ 4
}

\section{Abstract}

7 In the world of Philosophy for Children (P4C), the word "method" is found frequently in its

8 literature and in its practitioner's handbooks. This paper focuses on the idea of community

9 of philosophical inquiry (CPI) as P4C's methodological framework for educational purposes, and evaluates that framework and those purposes in light of the question, what does it mean to bring children and philosophy together, and what methodological framework, if any, is appropriate to that project? Our broader aim is to highlight a problem with regards to the concept of method in $\mathrm{P} 4 \mathrm{C}$, and to question the consequences of that concept in the practice of philosophical dialogue with children. To better situate the concept of method within P4C (which, we think, will help to clarify some of the dialogues and debates within $\mathrm{P} 4 \mathrm{C}$ as a philosophical field), we will identify two different historical understandingsrepresented by Rene Descartes and Hans Georg Gadamer-of the concept, and suggest new possibilities for understanding philosophical practice with children in light of their difference.

Keywords Method $\cdot$ Methodology $\cdot$ Philosophy for children $\cdot$ Inquiry

This is a shortened and different version of a previous paper, published in Portuguese, at Educação e Filosofia, Journal of the Instituto de Filosofia da Universidade Federal de Uberlândia, Brasil. The authors thank Cameron Duncan and David Kennedy for their contribution to the English of this text.

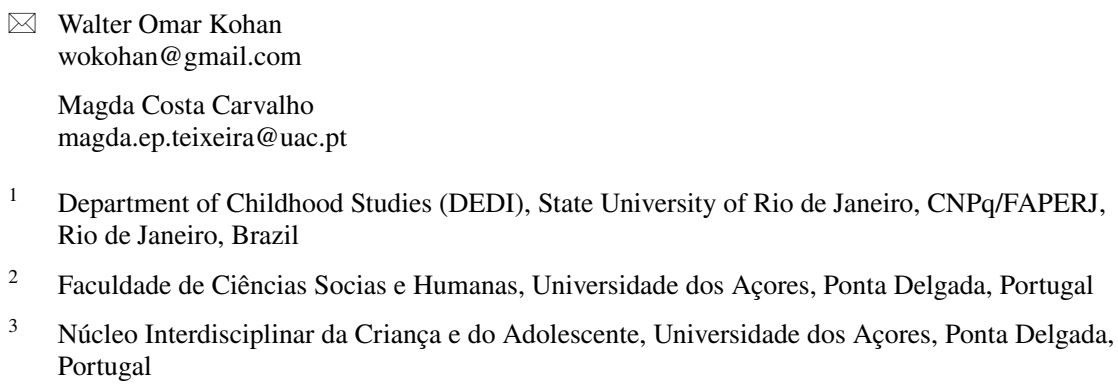


To think beyond the concept of method in the human sciences is to ask the question of the 'possibility' of the human sciences (which certainly does not mean what they really ought to be).

\section{Hans-George Gadamer}

This paper aims to highlight a problem with regards to the concept of method in the Philosophy for Children ${ }^{1}$ (P4C) movement, and also questions its consequences for the practice of philosophical dialogue with children. Can we consider the community of philosophical inquiry (Sharp 1987; Lipman 2003) to be a methodology? Does it require a specific (or many) method(s)? Should it even accept a methodological approach at all? In order to answer these questions, this paper begins by tracing the concept of method in the pragmatist philosophy of Charles Peirce and John Dewey, for these authors had a tremendous influence on Matthew Lipman and Ann Margaret Sharp, who were the founders of P4C as a curricular program in the 1970s. We go on to analyse the implications of Lipman's use of the words "method," "methodical" and "methodology" in his presentation of the community of philosophical inquiry for P4C.

The second part of the paper will explore the notion of method more generally. We will outline the etymology of the concept, stressing its main philosophical features according to the Cartesian tradition. René Descartes was not the only philosopher to look deeply into method: many others, like the hermeneutical thinker Hans-George Gadamer, questioned its assumptions. Guided by Gadamer's philosophical perspective, we will undertake an analysis of the word "method" in order to explore its different semantic possibilities. Finally, after we have questioned some key assumptions about methodology, we will invite the readers to think about the consequences of our questions as they engage in dialogue with children in their own communities of philosophical inquiry.

According to Vansieleghem \& Kennedy, the emphasis on methodology was the main characteristic of what they call the "first generation" of P4C theory and practice. The second generation experienced a shift from P4C as a method to P4C as a movement (2011, p. 172). Probably because of this, in recent times, experts in $P 4 C$ have noticeably shied away from raising questions on the topic of method, particularly when framed in relation to communities of philosophical inquiry. Method is, however, a word that still occurs frequently in P4C literature and in many practitioner handbooks (Juuso 2007, p. 63; Mizell 2015, p. 76; Duthie et al. 2018). Our paper focuses on the idea that the community of philosophical inquiry can be used as a methodological or pedagogical framework for educational purposes (Canon 2000; Vansieleghem and Kennedy 2012; Moriyón et al. 2018) and questions the implications of presenting it as such.

It is also significant, we claim, to question the methodologization of $\mathrm{P} 4 \mathrm{C}$ in general. To what extent would a method or methods transform $\mathrm{P} 4 \mathrm{C}$ into a practice vulnerable to instrumentalization, especially in present neoliberal educational times? Thus, we are proposing a

\footnotetext{
1FL01 ${ }^{1}$ Nowadays it is not easy to deal with the semantics of the expression "Philosophy for Children" or even 1FL02 with its acronym "P4C". It is contested by different practitioners, who consider it to be too narrow or that ${ }_{1 \mathrm{FL} 03}$ it is still too close to the curricular proposal that Matthew Lipman and Ann Margaret Sharp designed in the

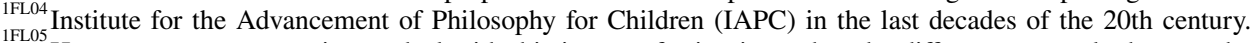
${ }_{1 \mathrm{FL} 06}$ However, we are not going to deal with this issue, referring instead to the different proposals that use the ${ }_{1 F L 07}$ community of philosophical inquiry approach. As a field of research, with the acronym P4C we refer to a 1FL08 philosophical area that encompasses the problematization of the different aspects (epistemological, ethical, ${ }^{1 F L 09}$ aesthetic, political, social) involved in philosophical practice with people of different ages, especially children.
} 
philosophical exercise through the problematization of $\mathrm{P} 4 \mathrm{C}$ as a methodology: this exercise involves (re)thinking the purposes of education in a manner that reanimates the question of what it means to bring childhood and philosophy together (Haynes and Murris 2012; Kohan 2014). ${ }^{2}$

We claim that a methodologist reading of $\mathrm{P} 4 \mathrm{C}$ runs the risk of transforming the practice of the community of philosophical inquiry into a technical approach, as well as intrumentalizing the process (Biesta 2017). We hope to open a door that will allow others to further the task of questioning what is done and why it is done the way it is, in a world where approaching children's education through philosophy seems a more urgent necessity than ever.

\section{Method in P4C}

The frequency of the appearance of the word method in $\mathrm{P} 4 \mathrm{C}$ literature might suggest a general consensus on its meaning and place within P4C. Lipman himself, on more than one occasion, used the phrase "the method of inquiry" to refer to the procedure of the community of philosophical inquiry $(2003$, p. $34 ; 48 ; 163 ; 172)$ and to the Institute for the Advancement of Philosophy for Children Curriculum as a pedagogical tool (Carvalho 1994).

Pragmatism was the key philosophical influence on Lipman and Sharp as they developed the foundations of P4C. Since the concept of method plays such a strong role in pragmatist philosophy, it is important to look there for insight into Lipman's and Sharp's use of the word. This might also prove to be meaningful in order to rethink method inside the community of philosophical inquiry as an educational setting, enabling us to discuss the extent to which method could actually act to restrain the activity of thinking in a community of philosophical inquiry, and even to thinking the community itself.

\section{P4C's Pragmatist Roots: "Not a Doctrine but a Method"}

The model of inquiry presented in $\mathrm{P} 4 \mathrm{C}$, and its concept of method, speaks clearly of the influence of the pragmatist philosophy of Peirce and Dewey on Lipman and Sharp. Peirce refers to the scientific method as the only method of inquiry capable of replacing doubt and fixating belief (1877); and Dewey states that philosophy should "cease to be a device for dealing with the problems of philosophers and become a method, cultivated by philosophers, for dealing with the problems of men" (Dewey 1995, p. 8). The philosopher William James refers to the pragmatist method as a way to solve metaphysical disputes that otherwise would be interminable (1975). Given the importance of the concept of method in the pragmatist tradition, it is unsurprising that Thinking in Education is the book in which Lipman uses the word "method" most frequently, and also where he most frequently quotes Peirce and Dewey. Lipman's point of entry into the pragmatist tradition is in evaluating the educational impact of the epistemological and even political assumptions of Peirce and Dewey's works, as well as the role that philosophical practice plays in it. Lipman argues that philosophy is possible only as a collective exercise, and he conceives the community

2FL01 ${ }^{2}$ For a recent update of different and very challenging possibilities to (re)think this relationship, see Jasin2FL02 ski 2018. 
of philosophical inquiry as its locus. In his understanding, it is urgent that educators take this communal exercise into schools, so that children might internalize collaborative thinking as early as possible.

Reflecting on these influences in his autobiography, Lipman writes: "What Dewey took from Peirce was not a doctrine but a method" (2003, p. 34). Therefore, within the pragmatist framework it is clear that the concept of method is not only a way to organize classroom activities but a procedure for thinking itself. Of all the pragmatist philosophers, it was Dewey who developed the concept of method within the context of a philosophy of education most thoroughly. He explored its implications as a way of understanding thinking and its development in school contexts. In Democracy and Education, he claims that "never is method something outside of the material" (2004, p. 179). Although the material of thinking might be analysed and discussed by itself, it does not necessarily exist per se, as the opposite element of the substance of thought. Method must not be understood as something formal, opposed to subject matter; if we look for something opposed to method, it is random and unconsidered action (Dewey 2004, p. 179). Therefore, mind analyzes method as the appropriate and intentional way of dealing with the subjects of thought. But it is clear that it does not exist in and of itself. How could one think without thinking about something? Hence, in educational contexts, the consequences of focusing strictly on method (what would be deemed a "methodologist" approach) would have undesired effects: First, it assumes the weak epistemological assumption that method and content are separable; and second, it replicates rigid pedagogical practices, presenting living and organic processes as if they were dry and empty formulas.

To hypostasize method would be a way to capture and entrench the educational process in mechanical routines. It would subsequently promote formative paths based on a readyto-wear model, in which individuals are treated homogeneously and subject to the same procedures. The danger is the reduction of educational practices to something akin to laboratory dissecting exercises, convincing teachers and educators that human experience can be generalized and measured accordingly. In a community of philosophical inquiry environment, such a strict methodological setting would comply with an approach that atrophies thinking more than it promotes it. In order to fully understand what is at stake here, let us look further into the use of the term "method" in Lipman and Sharp.

\section{Matthew Lipman and Ann Sharp: Method Might be Said in Many Ways}

In Thinking in Education, Lipman's major theoretical statement, the reader finds many occurrences of the word "method" as well as related linguistic variations like "methods", "methodology", "methodological", "methodical". Our first challenge was to find semantic equivalents to those variations, conforming their philosophical scope to the nature and terms of Lipman and Sharp's project of converting classrooms into communities of philosophical inquiry $(2003$, p. 20). The goal is not to insulate static concepts, but instead to identify different dimensions that might be articulated when one thinks about the concept of method in Lipman and Sharp's P4C Program. We approached their writings with a series of questions. In their work, can one categorize the community of philosophical inquiry as a method? If so, a method for what? Would it be preferable to say that the community of philosophical inquiry functions methodologically? And what does it mean to guide the philosophical practice of the community of philosophical inquiry in a methodical way? Furthermore, in view of all that has been built on Lipman and Sharp's seminal work, 
could method be too technical a concept for the nature and purposes of the community of philosophical inquiry? Which other meanings inhabit the term?

In our search for some clues to answer these questions, we will look at three crucial words in Lipman and Sharp's writings: "methodical", "methodology" and "method". We will embark on an archaeological journey in an attempt to identify their perspectives within the pragmatist approach to method presented above.

\section{Methodical}

In Lipman's works, "methodical" is the most general and the least technical term in use. It is what distinguishes an organized or systematic practice from a casual, unsystematic or disorganized one (Lipman 2003, pp. 14-15). With the term methodical Lipman refers to a practice that assumes a certain kind of regularity in its functioning whatever its specific purpose might be. In fact, Lipman claims that practice can only refer to an activity carried out in a methodical, organized, though not necessarily self-reflexive, way.

Surely, as long as P4C is understood as an experience with some consistency and inner organization it too is methodical. Thinking P4C in this way is too general for Lipman as it misses what distinguished $\mathrm{P} 4 \mathrm{C}$ from other methodical practices (whether in philosophy or not). Philosophical inquiry is methodical just like any other practice should be. In order for one to understand what is specific to the term in the community of philosophical inquiry, it is necessary to look deeper into the way Lipman refers to the notions of methodology and method.

\section{Methodology}

A related term in Lipman's writings is "methodology" (or "methodological") which contains a semantic specificity clearer than "methodical". Its meaning has to do with the procedures, perspectives, and points of view of the kind of thinking that a community of philosophical inquiry should welcome (Lipman 2003, p. 26).

Lipman refers to "reflective thinking," a mixed mode that overlaps two simple and incomplete forms of mental activity: procedural and substantive. Purely procedural thought is technical, and solely substantive thinking ends up crystallizing itself around contents. Reflective thinking does more than articulate methodology and content, since it involves reflection on methodology at the same time as it carefully examines its own subject matter (Lipman 2003, pp. 26-27).

Lipman's claims echo Dewey's refusal to define thinking in terms of a distinction between the method and the subject-matter of inquiry. In light of his pragmatist affiliation, Lipman opposes "straightforward" thinking and "complex thinking": the former deals only with the subject matter, while the latter combines subject matter with method (1995). Since the community of philosophical inquiry has complex (also called "reflective") thinking as its goal, it must nurture a recursive, metacognitive, self-correcting dialogue. ${ }^{3}$ For Lipman, complex or reflective thinking is thinking about the way one thinks. Metacognition, then.

\footnotetext{
3FL01 ${ }^{3}$ The philosophical model that Lipman quotes to illustrate this idea is in Euthyphro, where Plato handles 3FL02 two inquiries simultaneously: the inquiry on the concept of piety (the subject matter) and a second level of ${ }^{3} \mathrm{FL} 03$ inquiry that takes the first one as its own content.
} 
The participants in a community of philosophical inquiry are continuously encouraged to be self-aware and to verbalize both methodology and content. Through dialogical practice, the way the community thinks connects itself to what it thinks. Method and subject matter become mutually imbricated. For this reason, one should not impose a methodology that might be external or foreign to the very subjects of dialogue. Nor can method arrive prefabricated.

Revisiting the concept of reflective thinking and the larger goal of a community of philosophical inquiry, we stress, involves questioning procedures and subject matter of inquiry simultaneously. As Lipman states, "in deliberative inquiry in the classroom there must be continual awareness of the importance of the methodology of such inquiry all the while that matters of substance are being discussed." (Lipman 2003, p. 26, italics our own).

Lipman and Sharp offered P4C as a vehicle for converting the classroom into a community of philosophical inquiry. The word "conversion" might seem too strong, due to its religious connotation. Etymologically, the religious meaning of the word is derived from an earlier meaning: the act of turning or changing. It invokes the concepts of revolution or transformation. "Conversion" involves being opened to a new, transformative perspective that allows the reconstruction of new experiences and gives new senses to old ones (Sharp 1987, p. 43). This was what Lipman and Sharp had in mind when they claimed: "[In internaliz[ing] the methodology of the community as a whole, each [participant] is able to become self-correcting in his or her own thinking." (2003, p. 219). In this sense, converting is taking the community within oneself, being able to think in this way even when one is alone (Costa-Carvalho, Mendonça, 2017). Does this imply framing the community of philosophical inquiry approach to education as a method? The answer may lie in the way Lipman and Sharp use the very notion of method or at least in a certain interpretation of that use.

\section{Method}

We thus arrive at the direct use of the term "method." As previously noted, in addition to being understood as a set of cognitive procedures, method is a recurrent concept in Lipman's and Sharp's P4C Program and literature. It is also important in what it allows us to problematize regarding the nature of the community of philosophical inquiry.

The focus on the method of inquiry even as its substance is being articulated is, according to Lipman, one of the important dimensions of philosophy. It constitutes a difference between the community of philosophical inquiry and the traditional approach to education: it is about questioning and inquiring in a way that, on the one hand, organically articulates methodology and content and, on the other, recognizes that content itself is dependent on method: "you need these inquiry notions more," Lipman stated in an interview, "because they make the substantive ones possible, feasible. This is what philosophy generally does, it moves the focus from subject matter to method." (Kohan 1996).

In this last statement, is Lipman claiming that subject matter is less important than method? Do his words allow P4C practitioners to disregard the dialogical dimension and turn the community of philosophical inquiry into a set of formal logical and linguistic procedures? Or are these considerations posed on a meta-methodological level, since, in Lipman's view, the distinctive method of the P4C program consists precisely in an approach that focuses on thinking about the method? Right after the statement quoted above, Lipman stresses that "There are not two different substances. Method is the way in which we investigate the subject matter. But the method is nowhere, it is not something that flies or has 
shape, it is the method of investigation, that's why the whole dualistic problem is artificial or irrelevant for Dewey. Dualism is ridiculous for him. Mind is method, inquiry is method." (Lipman. In: Kohan 1996, p. 232)

The educational relevance of this concern for method is the fact that it allows children and adults in a community of philosophical inquiry to access the regulative and normative dimension of their own thinking. It deals with the criteria for what is said to be good and bad reasoning. The focus on method transforms simple cognitive activity into true deliberative work. According to Lipman, it is the community's aim to discuss and decide what constitutes good and bad thinking. Through reflective thinking-thinking that thinks about its own procedures - the community earns its right to identify, discuss and establish specific normative criteria. According to Lipman, this way of framing method as thinking about its own thinking moves education away from the unilateral (adult to child) transmission of content.

In the wake of John Dewey, Lipman assumes the task of overcoming the traditional bisubstantialist border between method and subject matter established by the Cartesian tradition. Mind and matter, or method and subject matter, cannot be regarded as two separate domains of knowledge, like form and content. In collaborative self-correcting inquiry there is no content without form and vice versa. Deliberative thinking is by definition inquiry that sets itself to think about the way it thinks, and therefore, it is open to meta-dialogue as well as meta-methodology.

\section{The Method of Inquiry: A Vaccine Against Bad Thinking?}

Despite the non-dualistic way of talking about method, Lipman also outlines it as a way to organize classroom activities, using phrases like "teaching methods" (2003, p. 11), "standard methods of problem solving" (2003, p. 65), "methods of teacher preparation" (2003, p. 10) or "didactic methods of instruction" (2003, p. 71). Earlier in the program's life, in an interview with a Brazilian newspaper, Lipman and Sharp explicitly refer to the P4C program as a method (in the sense of teaching procedures) that helps people to think for themselves (Carvalho 1994).

As we saw, what is practiced methodologically is a way of thinking that the members of the community learn together, and not so much the concepts, questions or even philosophical perspectives discussed. In this practice, Lipman and Sharp claim that the teacher has the essential role of initially knowing the method to apply, and modeling the way of thinking that the community is encouraged to adopt. The intention is not to establish the adult as the guardian of a method or technique that he or she alone can set in motion, but to make him or her into the mediator between the community and what the curriculum narratives (novels) and the pedagogical activities (manuals) offers. The community is intended to be a self-regulating community of philosophical inquiry within which the teacher is a mediator (2003, p. 14).

What prompted Lipman and Sharp to create P4C was a concern with what happens in traditional learning contexts, especially when the substance matters more than the form, and when thoughts interest us more than the way of thinking. The creators of $\mathrm{P} 4 \mathrm{C}$ highlighted the educational misconception of schools that focus more on content transmission and information acquisition: "It is not enough to learn what happened in history; we must be able to think historically." (2003, p. 24)

In the same way, one might say: it is not enough to learn what happened in philosophy; we must be able to think philosophically. The attention put on method was an educational 
difference that would warrant the community of philosophical inquiry to focus on the latter. As such, Lipman and Sharp considered educational activity as having significant social and political impact to the extent that it contributes to the formation of persons capable of reasonable thinking. Therefore, the way in which one organizes learning activities takes on considerable gravity. For Lipman, if schools do not adopt the method of inquiry they will not form people capable of inquiring and making sound judgments. That is to say, they will not form persons capable of building democratic ways of living. At its core educational activity is about investing in strengthening the quality of thinking (2003, p. 20).

Stressing the importance of ways of thinking is no new concern. European philosophers such as Francis Bacon, Descartes, and many others pondered on the importance of the way we think-the method of thinking. Lipman follows suit when he claims it is necessary to promote "some mental regimen or hygiene that people could impose upon themselves so as to immunize against the vicissitudes of bad thinking" (2003, p. 207). That is, it was important to endorse the method of thought which he considered to be philosophical inquiry. Philosophy understood as inquiry would, on his view, help to define problems and to think about them in critical, creative and caring ways, and this would contribute to democratic existence. More than a form of governance, democracy would be understood as form of inquiry: it would have to become a way of life (Dewey, 2004, p. 93).

Lipman and Sharp therefore proposed as a key element of P4C Program the procedures that would allow the conversion of classrooms into communities of inquiry. Notwithstanding the fact that they never dismissed the importance of content (all the novels present intentional philosophical concepts and are dedicated to specific philosophical areas), they stressed the importance of procedures in the community of philosophical inquiry. This may have been their way of highlighting P4C's specific difference from other educational approaches.

Forty years on, is it possible that their original approach to P4C struck too methodologist a tone? If one chooses to follow a technical or procedural reading of $\mathrm{P} 4 \mathrm{C}$, limiting the community of philosophical inquiry to strict method(s), it might turn philosophical dialogue into a rigid and instrumental pedagogical apparatus. In order to deal with the gap between the implicit design of the community of philosophical inquiry and a methodologist reading of $\mathrm{P} 4 \mathrm{C}$, we might put into question some broad historical assumptions regarding method itself. Research and practice in $\mathrm{P} 4 \mathrm{C}$, as well as the way the Program is presented to educators, will certainly benefit from questioning what lies beneath the surface when we approach the philosophical education of children from a methodological perspective.

\section{Philosophical Views on Method: Descartes and Gadamer}

Etymologically, "method" comes from the Greek méthodos, a word composed of the preposition metá (between, after, beyond) and of the noun hodós (way, road), meaning pursuit, search, substitution and its derivative looking for knowledge, research, way of inquiring, system (Liddell et al. 1966).

In Book VI of the Republic, as well as in other Platonic dialogues, the notion of method already plays an important role. In the modern age, a significant number of philosophers devoted entire works to the study of method. This is probably due to their proximity to the natural sciences. In the $17^{\text {th }}$ century, Francis Bacon published The New Organon, a book whose title might be translated precisely as "the new method." Bacon was looking for an innovative way to conduct scientific research, as opposed to traditional Aristotelian 
epistemology, which was based on logic. The peripatetic philosophers grouped Aristotle's logical works under the title of Organon ("Instrument"), in the sense of comprising the tools of philosophy. The Organon wasn't about Logics as a specific field of knowledge, but about logic understood as a set of tools for thinking. ${ }^{4}$

Of all the modern philosophers that thought about method, Descartes was not only the best known, but perhaps the most influential in shaping the way the subsequent philosophical tradition framed the concept. His Discours de la Méthode pour bien conduire sa raison et chercher la vérité dans les sciences gained such importance that, having been first published as a foreword to a book on Dioptric and Geometry, it soon became an autonomous text. Even after Descartes's mathematical and physical works lost their scientific relevance, the Discourse de la Méthode remained the standard for a particular kind of philosophical inquiry. The same happened with Regulae ad Directionem Ingenii, the Cartesian treatise that claimed that method was mandatory for inquiring into the truth of things.

Descartes defined method as the ordering and arranging of the objects of thought, and claimed it as a necessary (even if insufficient) condition to achieve reliable knowledge. It is only through method that natural intelligence orients itself in the use of mental operations (namely, intuition and deduction). Inquiring without method is far more harmful than helpful, Descartes claimed. "By 'a method', moreover, I understand certain and easy rulesrules such that, if one has followed them exactly, then one will never suppose anything false to be true, and, not having uselessly wasted any mental effort, but always gradually increasing knowledge, one will arrive at the true knowledge of all those things of which one will be capable." (Descartes 1998, p. 85) Descartes argues that method is a set of procedures that have to be properly (the word is "exactly") followed. Acting accordingly will prevent the intellect from being deceived and thus false will never be taken for true. A thought constructed in a methodological manner makes the greatest use of the rational abilities of each human being.

Descartes talks about procedures that most of the time he calls "rules." A method is a set of directives previously stated by reason which, when pursued in a strict way are able to avoid intellectual disorder and obscurity. Since a rule is not only a mode or course of action, but also a prescribed one, this normative character of method became one of its most influential features in the following centuries. After Descartes, to have a method would mean to have a series of mandatory steps to follow. This was considered the only way to access true knowledge.

Few philosophers have had such a striking effect on the semantics of the term "method" as Descartes. Hence, when method as a concept was transferred from epistemology to pedagogy and education, it adopted the meaning of a clearly defined set of (technical) procedures with a sequential order, in the image of the mathematical disciplines that produced so-called certified knowledge.

However, twentieth century Gadamerian philosophical hermeneutics explicitly questioned the Cartesian perspective on method. Gadamer rejected the relevance of a method conceived according to the modern model of science (the mathesis universalis) if it was understood as the only path towards truth. The philosopher's key work was published under the title Wahrheit und Methode (Truth and Method). The title is almost an ironic choice when one considers Gadamer's statement in the text: "I am not proposing a method; I am

4FL01 ${ }^{4}$ That was probably why Matthew Lipman named his first philosophical novel after Aristotle, Harry Stot4FL02tlemeier's Discovery, paying tribute to the first author of the so-called Western tradition who organized in ${ }^{4 \mathrm{FL} 03}$ his works the logical procedures for what was considered to be good reasoning. 
describing what is the case." (2004, p. 512). Nevertheless, Wahrheit und Methode became known as an icon for the humanities' resistance against the hegemony of the scientific concept of method (Lawn and Keane 2011, p. 92), refusing its universal applicability.

Claiming that there is truth beyond the strict notion of method and referring to the offerings of the human sciences, Gadamer offered the alternative notion of Bildung as a process of cultural formation. The author claimed: "What makes the human sciences into sciences can be understood more easily from the tradition of the concept of Bildung than from the modern idea of scientific method. It is to the humanistic tradition that we must turn. In its resistance to the claims of modern science it gains a new significance." $(2004$, p. 16).

Through Gadamer's appeal for humanistic openness, the status of method itself was put into question (Palmer 1969, p. 163). His famous debate with Emilio Betti raised the issue of hermeneutics as a science. Central was the question, should hermeneutics be considered a scientific discipline with normative methodological criteria? Put differently, should hermeneutics clearly state and define the difference between right and wrong interpretations? Gadamer saw this quest for validity as a search for the method that would warrant the interpreter the adequacy of his or her readings. This led him in another direction, which clarified the scope and purpose of hermeneutics: "That he [Betti] can conceive the problem of hermeneutics only as a problem of method shows that he is profoundly involved in the subjectivism which we are endeavouring to overcome. Obviously I have not succeeded in convincing Betti that a philosophical theory of hermeneutics is not a methodology-right or wrong ("dangerous"), as the case may be." (2004, p. 513)

Gadamer was interested in human modes of understanding (the hermeneutical experience). Recognizing and justifying its possibilities was a totally different task than prescribing how human beings should interpret their own experience of the world in order to produce valid assertions. It was in other words a leap beyond the concept of method into a distinctive way of addressing reality. According to Gadamerian hermeneutics, method confines the subject's experience of the object of inquiry, structuring in advance his or her encounter within a set of strict expectations. By using a method to approach reality, the subject engages in a kind of experience in which he or she is no longer surprised by what is found, but instead leads inquiry according to a pre-structured plan (Palmer 1969, p. 209). On the other hand, Gadamerian hermeneutics understand the inquirer to be questioned by the subject matter itself, adopting readiness and openness as ways of being in and experiencing the world. The Gadamerian subject seeks to be the servant of the text by following, participating and hearing what is said (Palmer 1969, p. 208); and most of all by being questioned in its own deepest assumptions.

Gadamer talks about the hermeneutical priority of the question, and stresses the limited nature of the idea of method in knowledge: "There is no such thing as a method of learning to ask questions, of learning to see what is questionable." (Gadamer 2004, p. 359).

It is not about mastering a sort of techné, in the Greek sense of the word, through which we can learn the technique for discovering truth in our inquiry. On the contrary, the hermeneutical model would be Socratic dialectic which, resisting dominant opinion, assumes questioning as the only way to escape an arrogant and self-validating sense of knowledge. This process of questioning is not compatible with any method that one can teach or learn; it is more an attitude that must be modelled to be understood (Weber and Wolf 2017, p. 80 ).

On this account, Cartesian and Baconian method may be a safe and reliable step-by-step approach to searching for answers to questions posed in advance, as is the case with modern science, but never a framework for a true picture of human experience. If "we cannot have experiences without asking questions" (Gadamer 2004, p. 356), then this means that 
real inquiry - which challenges settled assumptions and brings genuine change-emerges from a situation of epistemic doubt and instability. Understanding is a human noeetic process not fully grasped through a logic of validation grounded on objective measurement and verifiable proof (Palmer 1969, p. 64). The experiential path of being immersed in a reality that continuously questions us is not compatible with methodological unnilateralism. If all the methodological lines are drawn before we encounter reality, then nothing is left to say besides what is expected. And if something is said apart from those expectations, it probably will not be listened to.

As we argued at the beginning of this paper, P4C still lacks an extended discussion on method. Some of the ideas we have offered so far might be useful to start such a discussion: what can it say (or not say) regarding philosophical inquiry? In what ways does method challenge thinking (in) the community of philosophical inquiry?

\section{What Happens When the Community of Philosophical Inquiry Goes Beyond Methodology?}

After outlining Lipman and Sharp's understanding of method in P4C, and presenting the Cartesian reading on method, as well as the Gadamerian critique of its application to the humanities, let's reconsider some of our initial questions: does the community of philosophical inquiry require a method or method, or should it rather refuse one? What would be the consequences of using the concept of method to describe the nature of the community of philosophical inquiry? And how are educators to understand philosophical practice with children if it is framed in a methodological fashion? Is it just a matter of organizing classroom activities, or is it the case that such a framework may function as a Trojan horse for some unwelcome educational assumptions?

The phrase "method of inquiry" has become a hallmark for $\mathrm{P} 4 \mathrm{C}$ in such a way that the reference to the community of philosophical inquiry as a method for philosophical learning has been naturally and unquestioningly replicated. At some point, Lipman felt the need to state that what was specific about P4C, as opposed to approaches like Philosophy with Children (Murris 2016, pp. 3-4), was its institutionalized nature: "And this involves developing curricular materials and proper pedagogies." (Lipman 1999, p. 368). Almost ten years later, he would still claim that "There is a great deal more to the instigation and fostering of thinking than just having minds encounter problems. There needs to be a teacher, a pedagogy, a community of inquiry and a curriculum. The curriculum, in turn, needs to consist of specially prepared texts (such as stories imbued with philosophical distinctions, reasonings, and concepts)." (2008, p. 149). The manuals that Lipman wrote with Sharp and other colleagues to assist teachers in classroom activities with children were meant to propose specific activities that would fit with the Program's purposes. Accordingly, as we saw, in Thinking in Education Lipman uses the word "method" to refer to the mode of organizing those activities.

Likewise, the community of philosophical inquiry has been understood as having a methodology in the form of group dialogue, understood as a transformative systemic dynamics: "It creates its discussion agenda from questions which are posed by the interlocutors as a response to some stimulus-whether text or some other media — and includes discussion of specific philosophers or philosophical traditions, if at all, only in order to develop its own ideas together about the concepts under discussion." (Kennedy 2004, pp. 213-214). 
The community of philosophical inquiry has a structure of its own, and it adopts the Socratic ideal of philosophy as a political activity, insofar as it addresses, implicitly or explicitly, the organisation of power in schools (Kennedy and Kennedy 2012, p. 100). But did Socrates have a method to teach the love of thinking, and if so, are the early Platonic dialogues a record of this method? This question is not so easy to answer, especially in the context of a community of philosophical inquiry with children. Philosophical practice with children might be approached through Lipman's and Sharp's educational Program as a method for teaching philosophical concepts to children. The novels and manuals can be understood as giving teachers the necessary tools to set $\mathrm{P} 4 \mathrm{C}$ activities in motion, like a screenplay for theatre actors playing Shakespeare. But this, we claim, might not be the most interesting way to introduce and to practice $\mathrm{P} 4 \mathrm{C}$, especially when we consider the possibilities inherent in the activity of philosophical thinking with children.

Educators may ask what happens in philosophical inquiry when they use a strict methodological approach to P4C. It is claimed that this would be a path to promote a notion of philosophical progress, in the sense of providing children the opportunity to produce "better or more valuable conceptions, answers, propositions or judgments" (Golding 2010, p. 16). In this "problem-resolution conception of philosophical progress" (Golding, ibid.) inquiry is cut in a sequence of different stages, presenting specific tasks. Clinton Golding argues that 'the best guidance currently available, 'follow the inquiry where it leads', is not adequate for $\mathrm{P} 4 \mathrm{C}$ because it does not provide explicit scaffolding that $\mathrm{P} 4 \mathrm{C}$ students and teachers can use to judge what to do to advance their inquiry." (Golding 2010, pp. 103-104). Because the author rejects a linear and mechanistic approach to philosophical inquiry, he claims that he finds a "valuable heuristic device" in his stage-proposal, meaning that Golding sees it as a reference point for practitioners, especially novices, who after a while may even learn to be "more spontaneous and playful" in their philosophical inquiry.

However, we live in times of instrumentalization and "learnification" (Biesta 2017) in education, and the risk of reducing the community of philosophical inquiry to classroom exercises and pedagogical strategies is both philosophically and politically significant. If educational "progress" is taken to be the logo of philosophical inquiry, won't P4C be complying with an educational setting that presumes to be an industry for producing a certain kind of human beings, or that the value of the process is appreciated only in terms of its outcomes? We might look at the issue from a different perspective: what would happen in philosophical inquiry if educators decided to keep their distance from an exclusively methodological mindset?

We learn from Gadamer's critique of the Cartesian paradigm of method that questioning and understanding are not a universal path. In education, just as in life in general, pre-structured guidelines are but a small part of the game. They are the predictable part. How much of what happens in schools can be controlled? And what would be left behind if educators focused only on that part? How might one learn to be surprised by the world? How can we expect children to question their experiences if uncertainty, unsettledness and instability are removed from school's spaces of thinking?

Once we realize that community of philosophical inquiry goes far beyond the scope of (a) methodology, thinking can no longer be experienced as an isolated routine. Just like the six year old girl who, after eight months working with $\mathrm{P} 4 \mathrm{C}$, described philosophy as an adventure- "Yes, it is the adventure of knowing what we want to know with our whys," her five year old colleague replied. A very interesting choice of words we might add, for etymologically "ad-venture" means precisely something that is about to happen, that we will arrive at, that has not yet occurred and for this reason carries the risk of the unknown. If viewed solely through the lens of a methodology, what is left for the community 
"ad-venture" of philosophical inquiring? Understanding our experiences and dealing with the questions that underlie them demands the acceptance of the negativity of the unsettled and the unexpected. The "courage to depart cannot be planned or controlled by a method; rather it springs from an insatiable desire to grow." (Weber and Wolf 2017, p. 77) This is a process, Barbara Weber and Arthur Wolf stress, that cannot be captured just by a method, and for this reason they call upon the Gadamerian philosophical attitude presented above (Weber and Wolf 2017, p. 80).

Maybe it is not so much about teaching (with) methods, but, following a Heideggerian notion, about letting children learn; not a question of imposing P4C as a methodology, but of opening spaces so that philosophy might be (re)created whenever children's experiences call for it. Following this notion may lead to the construction of schools in which people had the freedom of six-year old Francisco, who responded to the adult who claimed to have taught him the lyrics of a Fado song): "You did not teach me! I learned it without you noticing it..."

At the Symposium, Socrates claims that he knows no other thing than the things of love (177d), and when it is his turn to praise eros, he says it was Diotima, a priestess from Mantineia - a woman and a foreigner-who taught him the things of love (201d). So Socrates does know at least one thing besides that he knows nothing, and it was taught to him by a foreign woman whose pedagogy was based on careful, detailed interrogation. Afterwards Socrates transcribed this learning experience as a dialogue, and this is precisely what Diotima taught Socrates-the love of thinking along with others. This is Socrates' passion, and maybe this is what we have to learn from him: the love of thinking with others, beyond any obedience to strict methodologies. Learning to love to think along with others comes from beyond us: not from a curriculum or a set of pedagogical stages. The only one capable of teaching something to Socrates is a figure of double exteriority - foreigner and woman - and Socrates himself is an equally improbable figure ("the most without place of all", a stranger in his city, a "lover of learning", Fedro, 230d).

For the contemporary French philosopher Gilles Deleuze, thinking originates in the external signs that force someone to think and require that they be deciphered, translated and exposed, in the all the senses that those signs carry. In this case, there is no method, either of thinking or learning, through which we learn how to think: "We never know in advance how someone will learn: by means of what loves someone becomes good at Latin, what encounters makes them a philosopher, or in what dictionaries they learn to think. The limits of the faculties are encased one in the other in the broken shape of that which bears and transmits difference. There is no more a method for learning, than there is a method for finding treasures, but a violent training a culture or paideia which affects the entire individual (an albino in whom emerges the act of sensing in sensibility, an aphasic in whom emerges the act of speech in language, an acephalous being in whom emerges the act of thinking in thought)." (1994, p. 165).

It is not a method that teaches one how to think, nor is it possible to learn how to think well with a method that is not sensitive to those (unpredictable) signs and signifiers of outside our familiar understandings from which thinking emerges. Thinking and learning are inherently problematic. They are problems that cannot be solved. Problems that are not meant to be solved.

What about us? Where do we, as practitioners of the encounter of philosophy with children, stand in relation to thinking and learning? When we enter a classroom, is it for the love of thinking with others? Is it this love to which we predispose ourselves? In what ways do we create the necessary invisibility and humility of teaching (to love) thinking? Do we love thinking enough not to want to reduce it to a teaching method; or enough to 
let learning to love it happen in other ways than our own? Do we create conditions in the classroom such that someone can learn to think in their own way? What do we seek after all - to teach childhood how to think or to learn a childhood of thinking? What do we hope for-that children learn how to think following our own ways of thinking, or that together we think in a childlike way as a testimony both of our love of thinking and our thinking about love?

Acknowledgements Funding was provided by Conselho Nacional de Desenvolvimento Científico e Tecnológico (Grant No. 202447/2017-0) and Fundação Carlos Chagas Filho de Amparo à Pesquisa do Estado do Rio de Janeiro (Grant No. E_03/2018).

\section{References}

Biesta, G. 2017. Touching the Soul? Exploring an Alternative Outlook for Philosophical Work with Children and Young People. Childhood \& Philosophy 13(28): 415-452.

Canon, D. 2000. How has Involvement with Philosophy for Children Changed How I/We Understand Philosophy? Analytic Teaching 22(2): 97-105.

Carvalho, B. 1994. Jogos cotidianos e lições metafísicas. Matthew Lipman fala sobre seu método de ensino. Folha de São Paulo, 1/5/1994. Caderno Mais.

Deleuze, G. 1994. Difference and Repetition. New York: Columbia University Press.

Descartes, R. 1998. Os Princípios da Filosofia. Lisboa: Guimarães Editores.

Dewey, J. 1995. The Political Writings. Indianapolis/Cambrigde: Hackett.

Dewey, J. 2004. Democracy and Education. An Introduction to the Philosophy of Education. Delhi: Aakar Books.

Duthie, E., F.G. Moriyón, and R. Loro. 2018. Parecidos de Familia. Propuestas Actuales en Filosofía para Niños. Family Resemblances. Current Trends in Philosophy for Children. Madrid: Anaya.

Gadamer, H.-G. 2004. Truth and Method. New York/London: Continuum.

Golding, C. 2010. "That's a better idea!" philosophical progress for philosophy for children. $\mathrm{PhD}$ thesis, Graduate School of Education \& School of Philosophy, Anthropology and Social Inquiry, The University of Melbourne, http://hdl.handle.net/11343/35757. Access: 08/20/2018.

Haynes, J., and K. Murris. 2012. Picturebooks, Pedagogy and Philosophy. New York and London: Routledge.

James, W. 1975. Pragmatism: A New Name for Old Ways of Thinking. Cambridge: Harvard University Press.

Jasinski, I. 2018. The Use of Philosophy with Children as a Pedagogical Practice. Theses, Dissertations and Culminating Projects. Upper Montclair: MSU, (Dissertation). Accessed March 3, 2019. https://digit alcommons.montclair.edu/etd/171.

Juuso, H. 2007. Child, Philosophy and Education Discussing the Intellectual Sources of Philosophy for Children. Oulu: Oulu University Press.

Kennedy, D. 2004. Communal Philosophical Dialogue and the Intersubject. International Journal of Applied Philosophy 18(2): 203-218.

Kennedy, N., and D. Kennedy. 2012. Community of Philosophical Inquiry as a Discoursive Structure, and its Role in School Curriculum Design. In Philosophy for Children in Transition. Problems and Prospects, ed. N. Vansieleghem and D. Kennedy, 97-116. Wiley-Blackwell: Malden.

Kohan, W.O. 1996. Two conversations with John Dewey and Matthew Lipman. In: Pensando la filosofía en la educación de los niños. México: Univ. Iberoamericana, Dissertation.

Kohan, W.O. 2014. Philosophy and Childhood. Critical perspectives and affirmative practices. New York: Palgrave.

Lawn, C., and N. Keane. 2011. The Gadamer Dictionary. New York: Continuum.

Liddell, Henry G., Robert Scott, and Henry Stuart James. 1966. A Greek English Lexicon. Oxford: Clarendon Press.

Lipman, M. 1995. Good Thinking. Inquiry: Critical Thinking Across the Disciplines 12(2): 37-41.

Lipman, M. 1999. Sobre a diferença entre 'filosofia para crianças', 'filosofia com crianças' e a 'filosofia da infância'. In Filosofia para crianças em debate, ed. W.O. Kohan and B. Leal, 362-364. Petrópolis: Vozes. 
Finding Treasures: Is the Community of Philosophical Inquiry...

Lipman, M. 2003. Thinking in Education. Cambridge: Cambridge University Press.

Lipman, M. 2008. Philosophy for Children's Debt to Dewey. In Pragmatism, Education and Children. International Philosophical Perspectives, ed. M. Taylor et al., 143-152. Amsterdam/New York: Rodopi.

Mizell, K. 2015. The Epistemology of Imagination and Play in the Community of Inquiry. Analytic Teaching and Philosophical Praxis 36: 76-87.

Murris, K. 2016. Philosophy with Picturebooks. In Encyclopedia of Educational Philosophy and Theory, ed. M. Peters. Singapore: Springer.

Moriyón, F., J. Botella, D. Centeno-Gutiérrez, and J.G. Lamas. 2018. Does Philosophy for Children make a Difference? In Parecidos de familia. Propuestas actuales en Filosofía para Niños/Family ressemblances. Current proposals in Philosophy for Children, ed. F. García, E. Duthie, and R. Robles, 421432. Madrid: Anaya.

Palmer, R.E. 1969. Hermeneutics. Interpretation Theory in Schleiermacher, Dilthey, Heidegger, and Gadamer, 1969. Evanston: Northwestern University Press.

Peirce, Ch.S. 1877. The Fixation of Belief. Popular Science Monthly 12: 1-15.

Sharp, A.M. 1987. What is a Community of Philosophical Inquiry? Journal of Moral Education 16(1): 37-44.

Vansieleghem, N., and D. Kennedy. 2011. What is Philosophy for Children, What is Philosophy with Children-After Matthew Lipman? Journal of Philosophy of Education 45(2): 171-182.

Vansieleghem, N., and D. Kennedy. 2012. Philosophy for Children in Transition: Problems and Prospects, 152-169. Malden, MA: Wiley-Blackwell.

Weber, B., and A. Wolf. 2017. Questioning the Question. A Hermeneutical Perspective on the 'Art of Questioning' in a Community of Philosophical Inquiry. In The Routledge International Handbook of Philosophy for Children, ed. M.R. Gregory, J. Haynes, and K. Murris, 74-82. London/New York: Routledge.

Publisher's Note Springer Nature remains neutral with regard to jurisdictional claims in published maps and institutional affiliations. 